\title{
SERUM CONCENTRATION OF THYROID HORMONES INCRIOULA LANADA SERRANA EWES IN GESTATION AND LACTATION
}

\author{
CONCENTRAÇÕES SÉRICAS DOS HORMÔNIOS TIREOIDIANOS \\ EM OVELHAS CRIOULA LANADA SERRANANA GESTAÇÃO E LACTAÇÃO
}

Colodel, M.M. ${ }^{1 \mathrm{~A}}$, Martins, E. ${ }^{2}$, Martins, V.M.V. ${ }^{1 \mathrm{~B}}$ and Marques Júnior, A.P. ${ }^{3}$

${ }^{1}$ Centro de Ciências Veterinárias-CAV. Universidade do Estado de Santa Catarina. UDESC. Av. Luiz de Camões, 2090. Bairro Conta Dinheiro. CEP 88520-100. Lages, SC. Brazil. Aa8mmc@cav.udesc.br; Ba2vmvm@cav.udesc.br

${ }^{2}$ Empresa de Pesquisa Agropecuária e Extensão Rural de Santa Catarina-EPAGRI. Estação Experimental de Lages. Rua João José Godinho, s/n. Bairro Morro do Posto. C.P. 181. CEP 88502-970. Lages, SC. Brazil. martinsev@terra.com.br

${ }^{3}$ Escola de Veterinária-UFMG. C.P. 567. CEP 30161-970. Belo Horizonte, MG. Brazil.

\section{AdDitionAl KEYWORDS}

Thyroid. Hormones. Reproduction.

\section{SUMMARY}

The effects of gestation and lactation on the dynamics of the thyroid hormones, triiodothyronine $\left(T_{3}\right)$ and thyroxine $\left(T_{4}\right)$ were evaluated in Crioula Lanada Serrana ewes from the plateau region in Santa Catarina - Brazil. To evaluate the effects of gestation, twenty four ewes were randomly divided into groups I and II. Group I was composed of 12 pregnant ewes and the control group (II) was composed of 12 non-pregnant ewes. The effects of lactation were evaluated in the same ewes of group I after parturition (LE) and in the control group (NL). Blood samples were taken in the first, second and third periods of gestation, at parturition, and at 30,60 and 90 days of lactation. $T_{3}$ and $T_{4}$ concentrations were determined by radioimmunoassay (RIA). Pregnant ewes showed lower serum concentrations of $T_{3}$ and $T_{4}$ than those of non-pregnant ewes. At parturition, there was no significant difference in $T_{3}$ concentrations between groups I and II ( $p>0.05)$. During lactation, serum $\mathrm{T}_{3}$ concentrations were lower $(p \leq 0.05)$ in LE than in $\mathrm{NL}$ ewes. Serum $\mathrm{T}_{3}$ concentrations were greater $(p \leq 0.05)$ at lambing than during the lactation periods. Serum $\mathrm{T}_{4}$ concentrations in LE at parturition did not differ $(p>0.05)$ from those of NL ewes. During lactation, $\mathrm{T}_{4}$ concentrations of LE were lower $(p \leq 0.05)$ than those of the NL ewes. The results of this study have shown that gestation

Recibido: 17-4-08. Aceptado: 4-2-09.

\section{PalaVRas ChaVe adicionaIS \\ Tireóide. Hormônios. Reprodução.}

causes a variation in the $T_{3}$ and $T_{4}$ serum concentrations, and that lactation results in a decrease of serum concentrations of $T_{3}$ and $T_{4}$ in Crioula Lanada Serrana ewes.

\section{RESUMO}

Os efeitos da gestação e lactação sobre a dinâmica dos hormônios tireoidianos triiodotironina $\left(T_{3}\right)$ e tiroxina $\left(T_{4}\right)$ foram avaliados em ovelhas Crioula Lanada Serrana na região do Planalto Serrano Catarinense. Para avaliar os efeitos da gestação, foram utilizadas vinte e quatro ovelhas distribuídas aleatoriamente em dois grupos. $O$ grupo I foi formado por 12 ovelhas gestantes e o grupo controle por 12 ovelhas não gestantes (grupo II). Os efeitos da lactação foram avaliados nas mesmas ovelhas do grupo I após a parição (LE) e no grupo controle (NL). Foram colhidas amostras sanguíneas no primeiro, segundo e terceiro terço da gestação, ao parto e aos 30,60 e 90 dias de lactação. As concentrações de $T_{3}$ e $\mathrm{T}_{4}$ foram determinadas por radioimunoensaio (RIA). As ovelhas gestantes apresentaram concentrações séricas de $T_{3}$ e $T_{4}$ inferiores àquelas não gestantes. Ao parto não houve diferença significativa nas concentrações de $T_{3}$ entre os grupos le ll $(p>0,05)$. Durante a lactação as concentrações

Arch. Zootec. 59 (228): 509-517. 2010. 
$\mathrm{de}_{3}$ foram menores $(\mathrm{p} \leq 0,05)$ para LE que para NL. No momento do parto, as concentrações de $T_{3}$ foram maiores $(p \leq 0.05)$ do que aquelas observadas no período de lactação e as concentrações de $\mathrm{T}_{4}$ em LE, não diferiram de NL. Durante a lactação as concentrações de $T_{4}$ de LE foram menores $(p \leq 0,05)$ do que em NL. Os resultados deste estudo demonstraram que a gestação causa variação nas concentrações séricas de $T_{3}$ e $T_{4}$ que, no momento do parto são similares àquelas observadas em ovelhas não gestantes. A lactação causa diminuição nas concentrações de $T_{3}$ e $T_{4}$ em ovelhas Crioula Lanada Serrana.

\section{INTRODUCTION}

The thyroid gland synthesizes the triiodothyronine $\left(\mathrm{T}_{3}\right)$ and thyroxine $\left(\mathrm{T}_{4}\right)$ hormones, which, directly or in combination with growth factors and hormones from other endocrine glands, are fundamental for the genesis and function of several organs. In addition, they play a role in a series of biochemical processes, triggering responses throughout the organism, including reproductive responses. Studies on the thyroid hormone dynamics in ovines have shown variations according to the sex, breed, age and physiologic state of the animals (Canola, 1982; Patel et al., 1992; Wells et al., 2003; Georgiev and Nikolov, 2004). The amount of iodine ingested and the daily food intake controls both $\mathrm{T}_{3}$ and $\mathrm{T}_{4}$ synthesis and secretion as well (Andrewartha et al., 1980; Rae et al., 2002).

The onset and continuation of homeostatic adjustments that occur during gestation depend on endocrine and neuro-endocrine mechanisms, of which the thyroid hormones, triiodothyronine $\left(\mathrm{T}_{3}\right)$ and thyroxine $\left(\mathrm{T}_{4}\right)$ play important regulating roles (Bergamashi et al., 2002). Some studies on the thyroid hormone dynamics in ovines have shown that there are variations in the concentration of thyroid hormones during lactation. However, the baseline serum thyroid hormone concentrations of the Crioula Lanada Serrana breed have not yet been determined. The availability of endocrine parameters of specific breeds, besides helping to prevent common neonatal illnesses such as hypothermia and hypoglycemia, may contribute to our understanding of the productive and reproductive potential of the Crioula Lanada Serrana ovine population. Furthermore, it could contribute to genetic improvement programs.

Crioula Lanada Serrana ewes raised in the plateau region of southern Brazil have faced climatic and nutritional adversities for four centuries, going through a process of natural selection and becoming highly adapted to the regional ecosystem (Vaz, 2000). Empiric observations of the fact that this breed offers a distinctive reproductive performance when compared to other animals of the species suggest the existence of highly adaptative endocrine and metabolic characteristics. Distinctive features observed include characteristics such as early puberty and high reproductive longevity and prolificity (Fernández, 2000), an enhanced maternal ability, births distributed throughout the year, low neonatal mortality rate and a large number of weaned lambs (Vazet al., 1999; Vaz et al., 2002).

In agreement with the above exposed reasons, the aim of this study was to determine the serum concentrations of $\mathrm{T}_{3}$ and $\mathrm{T}_{4}$ in Crioula Lanada Serrana ewes during gestation and lactation.

\section{MATERIALANDMETHODS}

The study was carried out at an ovine establishment in the plateau region of Santa Catarina. The region presents geographic coordinates of $27^{\circ} 49^{\prime}$ South latitude, $50^{\circ} 40^{\prime}$ West longitude from Greenwich and an average altitude of 884 meters. The region also presents an annual average temperature of $16.05^{\circ} \mathrm{C}\left(-4.00^{\circ} \mathrm{C}\right.$ to $32.30^{\circ} \mathrm{C}$ as minimum and maximum absolute temperatures, respectively), average relative air humidity of $79.95 \%$, a monthly average rainfall of 154.45 $\mathrm{mm}$, a maximum precipitation in 24 hours of 


\section{THYROID HORMONES IN EWES}

$114.45 \mathrm{~mm}$ and an average daily rainfall of 11.97 on rainy days. The environmental conditions of minimum and maximum daily temperatures during the experimental period were obtained at the meteorological station of the Estação Experimental de Lages/ EPAGRI. The serum levels of thyroid hormones $\mathrm{T}_{3}$ and $\mathrm{T}_{4}$ were evaluated in two experiments.

\section{EXPERIMENT 1}

Twenty four Crioula Lanada Serrana ewes, from one to four years old were used. The animals were randomly divided into two groups of twelve ewes each. The number of animals per age group was similar in both groups. Group I was composed of pregnant ewes and group II of non-pregnant ewes (control).

The twelve ewes from group I were breed to rams for 40 days, from February $1^{\text {st }}$ to March $11^{\text {th }}, 2004$. The 12 ewes from group II were not mated and served as controls. Mating was carried out at night, when the animals from groups I and II were separated, and the ewes from group I were placed together with a ram that was marked with paint on its chest so that upon mating the female would then become marked with paint herself. The ewes raised under free grazing conditions were kept during the whole experimental period in natural Axonopus jesuiticus pastures, where both groups received the same treatment.

All the ewes underwent four $10 \mathrm{ml}$ - blood sample collections by jugular venopuncture using vacutainer $20 \mathrm{GI} 1 / 2$ needles attached to vacuum tubes ${ }^{1}$. The blood samples from the pregnant ewes (group I) were collected at the end of the first third of the gestational period (40 to 50 days), at the end of the second third of the gestational period (90 to 100 days), at the end of the gestational period (140 to 150 days), and at the moment of parturition. Blood samples from non-

${ }^{1}$ Becton Dickinson Indústria Cirúrgica Ltda Curitiba, Paraná. Brazil. pregnant ewes (group II) were collected on the same collection days as the pregnant group.

\section{EXPERIMENT2}

The effects of lactation were evaluated in the same ewes of group I after parturition (LE group). Blood samples from the lactating ewes (LE) were collected at the moment of parturition, at the end of the first third of the lactation period (30 days), at the end of the second third of the lactation period (60 days), and at the end of the lactation period (90 days). Blood samples from non-lactating ewes (NL) were collected on the same days that the lactating group was sampled.

Blood samples were centrifuged at 1612 $\mathrm{x} \mathrm{g}$ for $15 \mathrm{~min}$ in order to separate the blood serum, which was placed in Eppendorfs tubes, properly identified, and stored at $-20^{\circ} \mathrm{C}$ for subsequent determination of $\mathrm{T}_{3}$ and $\mathrm{T}_{4}$ serum levels by radioimunoassay (RIA) method, in the solid phase using specific commercial ${ }^{2}$ kits for each hormone, for the in vitro diagnostic. The analyses were carried out at Bluegrass Embryo Transplant Laboratories (B.E.T. Laboratories), Rio de Janeiro, RJ, Brazil.

The experiments were entirely randomized in a $2 \times 4$ factorial, corresponding to the two treatments and 4 time periods. The numerical data of the $T_{3}$ and $T_{4}$ serum concentrations were statistically analyzed through variance of analysis. The treatments means were compared using the Student's $t$ Test at a significance level of $\mathrm{p} \leq 0.05$ (Snedecor and Cochran, 1994).

\section{RESULTS}

\section{EXPERIMENT 1}

The $\mathrm{T}_{3}$ serum concentration in Crioula Lanada Serrana ewes (table I) decreased from $1.49 \mathrm{ng} / \mathrm{ml}$ at the beginning of gestation to $1.27 \mathrm{ng} / \mathrm{ml}$ at the end of gestation $(\mathrm{p} \leq 0.05)$,

${ }^{2}$ Coat-A-Count ${ }^{\circledR}$. Diagnostic Products Corporation. Los Angeles. USA. 
Table I. Serum $T_{3}$ concentrations $(\mathrm{ng} / \mathrm{ml})$ in pregnant (group I) and non-pregnant (group II) Crioula Lanada Serrana ewes. (Concentrações séricas de $T_{3}(\mathrm{ng} / \mathrm{ml})$ em ovelhas da raça Crioula Lanada Serrana gestantes (grupo I) e não gestantes (grupo II)).

\begin{tabular}{ccccc}
\hline \multirow{2}{*}{ Groups } & \multicolumn{4}{c}{ Gestational ages (days) } \\
& $40-50$ & $90-100$ & $140-150$ & Parturition \\
& & & & \\
I & $1.49^{\mathrm{aA}}$ & $1.44^{\mathrm{abA}}$ & $1.27^{\mathrm{bA}}$ & $1.77^{\mathrm{aA}}$ \\
II & $1.81^{\mathrm{aB}}$ & $1.64^{\mathrm{aA}}$ & $1.75^{\mathrm{aB}}$ & $1.76^{\mathrm{aA}}$ \\
\hline
\end{tabular}

Means followed by different lower case letters in the same row or a different capital letter in the same column differ among each other by Student's "t" Test $(p \leq 0.05)$.

and increased at the moment of parturition. The variation in $\mathrm{T}_{3}$ in non-pregnant ewes, on corresponding days, was between 1.81 $\mathrm{ng} / \mathrm{ml}$ and $1.75 \mathrm{ng} / \mathrm{ml}$, not differing from the results found during the gestational periods $(p>0.05)$, nor in relation to the moment of parturition.

$\mathrm{T}_{3}$ serum concentrations in pregnant ewes, in the first and third thirds of gestation were lower than the concentrations in nonpregnant ewes $(p \leq 0.05)$. In the second third of gestation, the concentration in pregnant ewes was lower when compared to that of

Table III. Serum $T_{3}$ concentrations $(\mathrm{ng} / \mathrm{ml})$ in lactating ( $L E)$ and non-lactating (NL) Crioula Lanada Serrana ewes. (Concentrações séricas de $T_{3}(\mathrm{ng} / \mathrm{ml})$ em ovelhas da raça Crioula Lanada Serrana lactantes (LE) e não lactantes (NL)).

\begin{tabular}{lcccc}
\hline \multirow{2}{*}{ roup } & \multicolumn{4}{c}{ Days of lactation } \\
& parturition & 30 & 60 & 90 \\
\hline LE & $1.77^{\mathrm{aA}}$ & $1.43^{\mathrm{bA}}$ & $1.37^{\mathrm{bA}}$ & $1.38^{\mathrm{bA}}$ \\
$\mathrm{NL}$ & $1.76^{\mathrm{abA}}$ & $1.96^{\mathrm{aB}}$ & $1.67^{\mathrm{bB}}$ & $1.96^{\mathrm{aB}}$ \\
\hline
\end{tabular}

Means followed by different lower case letters in the same row or a different capital letter in the same column differ among each other by Student's "t" Test $(p \leq 0.05)$.
Table II. Serum $T$ concentrations $(\mathrm{ng} / \mathrm{ml})$ in pregnant (group I) and non-pregnant (group II) Crioula Lanada Serrana ewes. (Concentrações séricas de $T_{4}(\mathrm{ng} / \mathrm{ml})$ em ovelhas da raça Crioula Lanada Serrana gestantes (grupo I) e não gestantes (grupo II)).

\begin{tabular}{ccccc} 
Groups & \multicolumn{4}{c}{ Gestational ages (days) } \\
& $40-50$ & $90-100$ & $140-150$ & Parturition \\
& & & & \\
I & $38.74^{\mathrm{aA}}$ & $38.67^{\mathrm{aA}}$ & $37.92^{\mathrm{aA}}$ & $42.43^{\mathrm{aA}}$ \\
II & $48.53^{\mathrm{abB}}$ & $51.32^{\mathrm{aB}}$ & $45.41^{\mathrm{bB}}$ & $46.53^{\mathrm{abA}}$ \\
\hline
\end{tabular}

Means followed by different lower case letters in the same row or a different capital letter in the same column differ among each other by Student's "t" Test $(p \leq 0.05)$.

the non-pregnant ewes ( $p \leq 0.7)$, however, at the moment of parturition, it was similar to the concentration of the non-pregnant ewes.

There was no significant difference among the $T_{4}$ serum concentrations at the different gestational stages and the parturition day for group I ( $p>0.05)$. During gestation, group I values for $\mathrm{T}_{4}$ serum concentration were lower $(p \leq 0.05)$ when compared to the values of the non-pregnant ewes (group II) at the same points of time (table II). However, at the moment of parturition, there was no significant

Table IV. Serum $T_{4}$ concentrations $(\mathrm{ng} / \mathrm{ml})$ in lactating (LE) and non-lactating (NL) Crioula Lanada Serrana ewes. (Concentrações séricas de $T_{4}(\mathrm{ng} / \mathrm{ml})$ em ovelhas da raça Crioula Lanada Serrana lactantes (LE) e não lactantes (NL)).

\begin{tabular}{lcccc}
\hline Group & \multicolumn{4}{c}{ Days of lactation } \\
& parturition & 30 & 60 & 90 \\
\hline LE & $42.43^{\mathrm{aA}}$ & $34.66^{\mathrm{bA}}$ & $26.81^{\mathrm{bA}}$ & $27.50^{\mathrm{bA}}$ \\
$\mathrm{NL}$ & $46.53^{\mathrm{abA}}$ & $49.05^{\mathrm{aB}}$ & $41.56^{\mathrm{bCB}}$ & $39.38^{\mathrm{CB}}$ \\
\hline
\end{tabular}

Means followed by different lower case letters in the same row or a different capital letter in the same column differ among each other by Student's "t" Test $(p \leq 0.05)$.

Archivos de zootecnia vol. 59, núm. 228, p. 512. 


\section{THYROID HORMONES IN EWES}

difference $(p>0.05)$ between the concentrations of the two groups.

\section{EXPERIMENT2}

At parturition, there was no significant difference in $\mathrm{T}_{3}$ concentrations between LE and NL ewes ( $p>0.05)$. At all points of time evaluated during lactation, the serum $T_{3}$ concentrations were lower $(\mathrm{p} \leq 0.05)$ in the lactating ewes when compared to the nonlactating ewes (table III).

In the LE, at the moment of parturition, the serum $\mathrm{T}_{3}$ concentrations were greater $(p \leq 0.05)$ than those from the lactation periods (table III).

Serum $\mathrm{T}_{4}$ concentrations in LE did not differ from those of NL ewes at the moment of parturition. At 30, 60 and 90 days of lactation (table IV), $\mathrm{T}_{4}$ concentrations of LE were lower $(p \leq 0.05)$ than those of the NL ewes.

\section{DISCUSSION}

The lower $\mathrm{T}_{3}(1.49 \mathrm{ng} / \mathrm{ml})$ and $\mathrm{T}_{4}(38,7 \mathrm{ng} /$ $\mathrm{ml}$ ) concentrations in the first third of gestation in comparison with the nonpregnant ewes $\left(\mathrm{T}_{3}=1.81 \mathrm{ng} / \mathrm{ml}\right.$ and $\mathrm{T}_{4}=48.53$ $\mathrm{ng} / \mathrm{ml}$ ), could be related to the passage of thyroid hormones through the placenta, since the ovine thyroid becomes functional only between the sixth and eighth weeks of embryonic life (Bryden et al., 1972). According to Escobar (2001), the mother is the only source of $\mathrm{T}_{3}$ and $\mathrm{T}_{4}$ up to the moment that the thyroid tissue becomes active in the fetus and plays its role in organogenesis and in the development of the placenta.

The decrease in maternal $\mathrm{T}_{3}$ and $\mathrm{T}_{4}$ serum concentrations, respectively, in the second third $(1.44 \mathrm{ng} / \mathrm{ml} ; 38.67 \mathrm{ng} / \mathrm{ml})$ and the last third $(1.27 \mathrm{ng} / \mathrm{ml} ; 37.92 \mathrm{ng} / \mathrm{ml})$ of gestation, in comparison to $\mathrm{T}_{3}(1.64 \mathrm{ng} / \mathrm{ml} ; 1.75 \mathrm{ng} / \mathrm{ml})$ and $\mathrm{T}_{4}(38.67 \mathrm{ng} / \mathrm{ml} ; 37.92 \mathrm{ng} / \mathrm{ml})$ of nonpregnant ewes during these periods, repectively, could be related, according to Bergamashi et al. (2002), to iodine uptake by the fetus through the placenta. Indeed, during the first third of gestation, the fetal thyroid is not functional and it needs no iodine, as it does not form thyroid hormones. However, as the fetus becomes more developed, it begins to produce its own thyroid hormones and it requires maternal iodine in increasing amounts for the hormonal synthesis. The iodine requirement increases mainly in the last third of gestation, when $87 \%$ of the circulating maternal iodine is transferred to the fetus (Falconer, 1963), coinciding with the period of highest fetal growth (Campos et al., 1993). At the end of the gestation, the fetal hypothalamic-pituitary-thyroid axis in the ovine works independently from the maternal axis and there is little transference of $\mathrm{T}_{3}$ and $\mathrm{T}_{4}$ from the mother to the fetus (Nathanielsz, 1975).

The lower $\mathrm{T}_{3}$ and $\mathrm{T}_{4}$ serum concentrations in pregnant ewes in comparison to non-pregnant ewes could be related to the enzymatic activity of deiodinase. According to Kelly (2000), type 2 deiodinase is probably responsible for the maintenance of adequate local $\mathrm{T}_{3}$ concentrations, and type 3 deiodinase transforms $\mathrm{T}_{3}$ and $\mathrm{T}_{4}$ into inactive metabolites. Acting together, type 2 and 3 deiodinases may reduce thyroid hormone concentration during gestation.

The $T_{4}$ values shown in this study differ from the findings presented by Chopra et al. (1975) who compared pregnant ewes in the last third of gestation with non-pregnant ewes (Columbia breed or a Columbia x Suffolk cross-breed), and observed no variation in the concentrations of this hormone.

The higher $\mathrm{T}_{3}$ concentration in the first third of gestation $(1.49 \mathrm{ng} / \mathrm{ml})$ compared to the second $(1.44 \mathrm{ng} / \mathrm{ml})$, and this concentration compared to that of the final third $(1.27 \mathrm{ng} / \mathrm{ml})$, could be related to the gradual increase of iodine transfer through the placenta, as well as to the significant increase in the urinary excretion of iodine during gestation due to maternal glomerular filtration (Burrow et al., 1994).

The higher $\mathrm{T}_{3}$ concentration at partu- 
rition $(1.77 \mathrm{ng} / \mathrm{ml})$ compared to the three gestational periods $(1.49 ; 1.44 ; 1.27 \mathrm{ng} / \mathrm{ml}$ for the first, second and last third, respectively) could be due to the action of glucocorticoids, which in ovines increase progressively in the last thirteen days before parturition (Chopra et al., 1975). Cortisol stimulates hepatic and renal deiodination from $T_{4}$ to $T_{3}$ by type 1 deiodinase. In addition, the cortisol wave at pre-parturition and at parturition increases the circulating $\mathrm{T}_{3}$ concentration and may reduce the $\mathrm{T}_{4}$ serum concentration (Graf and Carvalho, 2002). However, a decrease in the $T_{4}$ concentration was not observed in the present study, and its value at parturition $(42.43 \mathrm{ng} / \mathrm{ml})$ did not differ from the values observed at the three points of time during gestation $(38.74 ; 38.67 ; 37.92 \mathrm{ng} / \mathrm{ml}$ for the first, second, and last third respectively).

The $\mathrm{T}_{4}$ results cited above related to the gestational phases differ from the results found by Aumont et al. (1989) and Wallace et al. (1997) who studied the thyroid dynamics in Suffolk, Dorset and crossbreeds, and found a reduction from the last third of gestation up to the moment of parturition when compared to the other gestational phases. This divergent result may be responsible for the large number of weaned lambs and the excellent maternal ability, remarkable characteristics of the Crioula Lanada breed. Nevertheless, this is a question that needs further investigation in animals of different breeds exposed to the same management and environmental conditions.

In the non-pregnant ewes (Group II), changes in $\mathrm{T}_{4}$ serum concentrations (table II) were observed only between the periods that corresponded to the second and third gestational periods of the animals of group $\mathrm{I}(\mathrm{p} \leq 0.05)$. This finding is likely to be related to intrinsic and extrinsic factors, since the collection of blood samples in May coincided with noticeable drops in the temperature, characteristic of the plateau region of Santa Catarina. As thyroid hormone liberation brings about an increase in thermogenesis and in the consumption of energy (Douglas, 2002), it may be possible that the availability of these hormones varies in response to changes in the caloric or thermal conditions of the organism. Therefore, significant differences between the values obtained in different months of collections were expected. This result is similar to that found by Nascimento et al. (1997) and Andrewartha et al. (1980), who observed seasonal changes in serum concentrations of thyroid hormones in ovines.

The results obtained for lactating ewes differ from those found by Henneman et al. (1955) who observed increased secretion of thyroid hormones in lactating ewes of the Shoropshire breed when compared to nonlactating ewes. Similarly, Falconer (1963) did not find a difference in thyroid hormone concentrations in Merino ewes between the two physiological stages.

In the present work, the lower $\mathrm{T}_{3}$ and $\mathrm{T}_{4}$ concentrations throughout the lactation period in relation to the NL ewes may have occurred as a result of the decrease in thyroid secretion. According to Bauman and Currie (1980), Refsal et al. (1984), Bauman (1992) and Tiirats (1997), the decrease in the secretion of thyroid hormones occurs as a result of an insufficient energy supply in the extra-mammary tissues, due to the intense consumption of nutrients by the mammary gland during lactation. During this period, when milk is produced and mammary gland activity increases, a mobilization of body fat, a loss in weight and a negative energetic balance occur as a consequence of the mammary gland's demand of glucose, amino acids and fatty acids.

The lower secretion of hormones by the thyroid gland, which may have reduced the $\mathrm{T}_{3}$ and $\mathrm{T}_{4}$ concentrations throughout the lactation period in this study, may have also occurred because thyroid hormones increase the secretion of insulin (Guyton and Hall, 2002). According to Achmadi and Terashima 


\section{THYROID HORMONES IN EWES}

(1995), the reduction in serum concentration of $\mathrm{T}_{3}$ can decrease the secretion of insulin in sheep. The reduced concentrations of thyroid hormones, in association with a low concentration of insulin during lactation, promote the mammary gland's preferential utilization of the substrates (Gueorguiev, 1999). Also according to Gueorguiev (1999), an increase in thyroid hormone secretion during lactation would be unfavorable for the physiologic adjustment to milk production, because some of its precursors, especially glucose, would be directed to the extra-mammary tissues, such as the adipose tissue and the muscles.

The lower serum concentration of $\mathrm{T}_{3}$ and $\mathrm{T}_{4}$ observed in the LE ewes when compared to the NL in this study could also be attributed to the mammary gland's demand for thyroid hormones (Akasha et al., 1987). At the beginning of lactopoiesis, there is an increase in the number of $\mathrm{T}_{3}$ receptors in the mammary gland's secretory cells during lactation (Wilson and Gorewit, 1980) and there is a greater activity of the organspecific type 2 deiodinase enzyme, which generates $\mathrm{T}_{3}$ intracelullarly from $\mathrm{T}_{4}$ and also of the type 3 deiodinase enzyme, which in turn deactivates the thyroid hormones (Kahl et al., 1998; Pezzi et al., 2003); and there is an actual secretion of $\mathrm{T}_{4}$ through the milk, which may represent between $4 \%$ and $7 \%$ of the total required for the maintenance of metabolic functions (Akasha and Anderson, 1984). In addition, the decrease in $T_{4}$ concentrations in the LE ewes could yet be caused by the additional mammary gland's excretion of maternal iodine during lactation, since $55.66 \%$ of ovine circulating iodine is excreted by the milk, which is the reason that the concentration of iodine in milk and

\section{REFERENCES}

Akasha, M. and Anderson, R.R. 1984. Thyroxine and triiodothyronine in milk of cows, goats, sheep, and guinea pigs. Proc. Soc. Exper. Biol. Med., 177: 360-371. in the blood serum are, respectively, 29:1 and 92:1 (Falconer, 1963).

In this study, as stated before, the higher serum concentration of $\mathrm{T}_{3}$ on the day of parturition $(1.77 \mathrm{ng} / \mathrm{ml})$ when compared to the periods of lactation could be related to the glucocorticoid concentrations, which increase at the end of gestation (Chopra et al., 1975; Mathur et al., 1980). The glucocorticoids stimulate the hepatic and renal deiodination of $\mathrm{T}_{4}$ and $\mathrm{T}_{3}$, which increases the serum concentration of $\mathrm{T}_{3}$ and may decrease the concentration of $\mathrm{T}_{4}$ (Thomas et al., 1978; Graf and Carvalho, 2002). However, a decrease in the concentration of $\mathrm{T}_{4}$ was not observed in this study, in which their values of $42.43 \mathrm{ng} / \mathrm{ml}$ immediately after parturition and $34.66 \mathrm{ng} /$ $\mathrm{ml}$ at 30 days of lactation were greater than the concentrations observed at 60 and 90 days of lactation $(26.81$ and $27.50 \mathrm{ng} / \mathrm{ml}$, respectively). These results differ from those found by Falconer (1963) and Andrewartha et al. (1980) who did not observe differences between the serum concentrations of the thyroid hormones of Australian ewes in the first two stages of lactation.

\section{CONCLUSION}

The findings obtained, in the conditions under which the experiment was carried out, allow us to conclude that for the Crioula Lanada Serrana breed the physiological stage of gestation causes a variation in the $\mathrm{T}_{3}$ and $\mathrm{T}_{4}$ serum concentrations, which at the moment of parturition are similar to the concentrations observed in non-pregnant ewes. Also in this breed, during lactation, there is a decrease in serum concentrations of $\mathrm{T}_{3}$ and $\mathrm{T}_{4}$.

Akasha, M.A., Anderson, R.R., Ellersieck, M. and Nixon, D.A. 1987. Concentration of thyroid hormones and prolactin in dairy cattle serum and milk at three stages of lactation. J. Dairy 


\section{COLODEL, MARTINS, MARTINS AND MARQUES JÚNIOR}

Sci., 70: 271-276.

Achmadi, J. and Terashima, Y. 1995. The effect of propylthiouracil-induced low thyroid function on secretion response and action of insulin in sheep. Domestic. Anim. Endocrinol., 12: 157166.

Andrewartha, K.A., Caple, I.W., Davies, W.D. and Mcdonald, J.E. 1980. Observations on serum thyroxine concentrations in lambs and ewes to assess iodine nutrition. Aust. Vet. J., 56: 18-21.

Aumont, G., Lamand, M. and Tressol, J.C. 1989. lodine nutrition in ewes: effects of low to high iodine intake on iodine content of biological fluids in pregnant and lactating ewes. Reprod. Nutr. Dev., 29: 113-125.

Bauman, D.E. 1992. Bovine somatotrophin: review of an emerging animal technology. J. Dairy Sci., 75: 3432-3451.

Bauman, D.E. and Currie, W.B. 1980. Partitioning of nutrients during pregnancy and lactation: a review of mechanisms involving homeostasis and homeorhesis. J. Dairy Sci., 63: 1514-1529.

Bergamashi, M.A.C.M., Vicente, W.R.R., Barbosa, R.T., Marques, J.A. e Freitas, A.R. 2002. Perfis plasmáticos maternos de triiodotironina e tiroxina em fêmeas nelore e crescimento fetal bovino. Rev. Bras. Med. Vet., 25: 35-39.

Bryden, M.M., Evans, H.E. and Binns, W. 1972 Embriology of the sheep. II. The alimentary tract and associated glands. J. Morphol., 138: 187206.

Burrow, G.N., Fisher, D.A. and Larsen, P.R. 1994. Maternal and fetal thyroid function. N. Engl. J. Med., 331: 1072-1078.

Campos, R., Díaz, F. y Wilches, M. 1993. Hormonas tireoideanas durante la gestacion: nivelis sericos en la madre y en el feto. Acta Agron., 43: 156159.

Canola, J.C. 1982. Determinação, por radioimunoanálise, dos níveis séricos de triiodotironina $e$ tiroxina, em ovinos da raça Corriedale do Rio Grande do Sul. Universidade Federal de Santa Maria. Dissertação. Santa Maria. Brasil.

Chopra, I.J., Sack, J. and Fisher, D.A. 1975. 3,3',5'triiodothyronine (reverse $T_{3}$ ) and 3,3 ',5triiodothyronine $\left(T_{3}\right)$ in fetal and adult sheep: studies of metabolic clearance rates, production rates, serum binding, and thyroidal content relative to thyroxine. Endocrinology, 97: 10801088.
Douglas, C.R. 2002. Fisiologia da glândula tireóide. Em: Douglas, C.R. Tratado de fisiologia aplicado à saúde. $5^{\mathrm{a}}$ ed. Robe Editorial. São Paulo. pp. 1211-1231.

Escobar, G.M. 2001. The role of thyroid hormone in fetal neurodevelopment. J. Pediatr. Endocr. Met., 14: 1453-1462.

Falconer, I.R. 1963. lodide metabolism of the thyroid and mammary glands during lactation in sheep. J. Endocrinol., 25: 533-539.

Fernández, G. 2000. Situación de los recursos genéticos domésticos locales del Uruguay. Arch. Zootec., 49: 333-340.

Georgiev, P. and Nikolov, Y. 2004. Blood chemical and endocrine changes in sheep with experimental chronic acidosis. Bulg. J. Vet. Med., 7: 149-153.

Graf, H. e Carvalho, G.A. 2002. Fatores interferentes na interpretação de dosagens laboratoriais no diagnóstico de hiper e hipotireoidismo. Arq. Bras. Endocrinol. Metab., 46: 51-64.

Gueorguiev, I.P. 1999. Thyroxine and triiodothyronine concentrations during lactation in dairy cows. Ann. Zootech., 48: 477-480.

Guyton, A.C. e Hall, J.E. 2002. Tratado de fisiologia médica. $10^{\mathrm{a}}$ ed. Ed. Guanabara Koogan. Rio de Janeiro. 1008 pp.

Henneman, H.A., Reineke, E.P. and Griffin, S.A. 1955. The thyroid secretion rate of sheep as affected by season, age, breed, pregnancy and lactation. J. Anim. Sci., 14: 419-434.

Kahl, S., Elsasser, T.H. and Rumsey, T.S. 1998. Regulation of thyroid hormone action: 5 deiodinase. In: Proceeding of $1^{\text {st }}$ Symposium on Growth in Ruminant: Basic Aspects. Theory and Practice for the Future, 1998. Switzerland. pp. 168-177.

Kelly, G. 2000. Peripheral metabolism of thyroid hormones: a review. Altern. Med. Rev., 5: 306332.

Mathur, H., Brown, B.L., Krane, E.J., Thomas, A.L. and Nathaniels, P.W. 1980. Thyroid hormone relationships in the fetal and newborn lamb. Biol. Neonate, 37: 138-141.

Nascimento, M.R.B.M., Silva, R.G. and Dantas, M.A. 1997. Effect of air temperature and humidity on the variation of the serum levels of thyroid hormones in corriedale sheep. ARS Veterinária, 13: 209-217.

Archivos de zootecnia vol. 59, núm. 228, p. 516. 


\section{THYROID HORMONES IN EWES}

Nathanielsz, P.W. 1975. Thyroid function in the fetus and newborn mammal. Brit. Med. Bull., 31: 51-56.

Patel, J.S., Mehta, V.M., Tajane, K.R. and Kulkarni, W. 1992. Effect of thermal exposure on some of the hormones in Patanwadi and its crosses. Indian Vet. J., 62: 89-90.

Pezzi, C., Accorsi, P.A., Vigo, D., Govoni, N. and Gaiani, R. 2003. 5'-deiodinase activity and circulating thyronines in lactating cows. J. Dairy Sci., 86: 152-158.

Rae, M.T., Rhind, S.M., Kyle, C.E., Miller, D.W. and Brooks, A.N. 2002. Maternal undernutrition alters triiodothyronine concentrations and pituitary response to $\mathrm{GnRH}$ in fetal sheep. J. Endocrinol., 173: 449-455.

Refsal, K.R., Nachreiner, R.F. and Anderson, C.R. 1984. Relationship of season, herd, lactation, age and pregnancy with serum thyroxine and triiodothyronine in Holstein cows. Domestic. Anim. Endocrinol., 1: 225-234.

Snedecor, G.W. and Cochran, W.G. 1994 Statistical methods. $8^{\text {th }}$ ed. lowa State University Press. Ames. 503 pp.

Tiirats, T. 1997. Thyroxine, triiodothyronine and reverse-triiodothyronine concentrations in blood plasma in relation to lactational stage, milk yield, energy and dietary protein intake in Estonian dairy cows. Acta Vet. Scand., 38: 339-348.

Thomas, A.L., Krane, E.J. and Nathanielsz, P.W. 1978. Changes in the fetal thyroid axis after induction of premature parturition by low dose continuous intravascular cortisol infusion to the fetal sheep at 130 days of gestation. Endocrinology, 103: 17-23.

Vaz, C.M.S.L., Bialkowski, J.G., Andrade, S.F.J.,
Matos, C.W. e Bertan, H. 2002. Comportamento da raça ovina Crioula durante a parição. Em: Anais do Congresso Brasileiro de Medicina Veterinária (Conbravet), 24; Congresso Estadual de Medicina Veterinária, 15; Congresso de Medicina Veterinária do Conesul, 4; Congresso Estadual da Anclivepa-RS, 1; Exposição de Produtos e Serviços em Medicina Veterinária (EXPOVET), 8; 2002, Gramado, Brasil [CD-ROM].

Vaz, C.M.S.L., Bricarello. P.A., Gonçalves, I.G.E. e Vaz, C.S.L. 1999. Comportamento de cordeiros das raças Crioula Lanada e Corriedale frente ao aleitamento artificial. Em: Anais do Congreso Latinoamericano de Especialistas em Pequeños Ruminantes y Camélidos Sudamericanos, 1; Jornadas Uruguayas de Ovinos, 11; Encontro de Medicina de Pequenos Ruminantes do Cone Sul, 2; 1999, Montevideo, Uruguay [CD-ROM]. Montevideo: AVEPER.

Vaz, C.M.S.L. 2000. Morfologia e Aptidão da Ovelha Crioula Lanada. EMBRAPA Pecuária Sul. Bagé. 20 pp. (EMBRAPA Pecuária Sul. Doc., 22).

Wallace, J.M., Silva, P., Aitken, R.P. and Cruickshank, M.A. 1997. Maternal endocrine status in relation to pregnancy outcome in rapidly growing adolescent sheep. J. Endocrinol., 155: 359-368.

Wells, N.H., Hallford, D.M. and Hernandez, J.A. 2003. Serum thyroid hormones and reproductive characteristics of Rambouiellet ewe lambs treated with propylthiouracil before puberty. Theriogenology, 59: 1403-1413.

Wilson, D.B. and Gorewit, R.C. 1980. Specific thyroxine receptors in mammary cytosol from lactating cattle. Biochem. Biophys. Res. Commum., 95: 807-815. 